\title{
An Analysis of EFL Learners' Integrative and Instrumental Motivation Factor at English Language Education Undiksha
}

\author{
Made Surya Mahendra ${ }^{1}$ \\ Universitas Pendidikan Ganesha, Indonesia \\ suryahendra188@gmail.com \\ Ni Luh Putu Eka Sulistia Dewi ${ }^{2}$ \\ Universitas Pendidikan Ganesha, Indonesia \\ sulistia.dewi@undiksha.ac.id \\ Ida Ayu Made Istri Utami ${ }^{3}$ \\ Universitas Pendidikan Ganesha, Indonesia \\ istriutami@undiksha.ac.id
}

\begin{abstract}
This study aimed (1) to analyze motivation's factor that affects English Language Education Students in achieving learning English both in instrumental and integrative motivation; (2) to analyze the major factor of motivation that affect students; and (3) to analyze how the major factor of motivation influence the students in achieving their goal in learning English. The survey was employed as a method of data collection through questionnaires and interviews. Both instruments consisted of instrumental and integrative motivation, which each dimension involves three factors of motivation. The results showed that English Language Education students were affected by six motivation factors. Those are academic, social, economic, attitude toward learning the target language, attitude toward the target language community, and desire to learn the target language. Among those motivation factors, the academic and attitude toward learning the target language were the major factor that affects students in achieving their goal in language learning.
\end{abstract}

Keywords: Motivation, Instrumental Motivation, Integrative Motivation

\section{INTRODUCTION}

English has become one of the international languages that most people around the world already used to communicate with others from another country. In Indonesia, English is widely recognized as an important language with a reason for this is because English is a global or international language. According to Crystal (2003), more than hundred million speakers have been using English as first language, second language and foreign language. It indicates that English is very essential for a tool of communication.

Besides as an international language, students have several reasons for why they learn English. There are three different reasons of students to learn English, i.e. to get a better job, to make them capable in communicating with others people around the world, to increase someone's confidence when go to abroad (Fachraini, 2017). Nowadays, the importance of English leads some people to learn the language including students in Ganesha University of Education. This university consists of many faculties which are divided into two areas. One of them is Language and Art Faculty which focuses on the education of language and art. Based on the observation, English Language 
Education becomes the most popular program compared with the other study program. However, among all students who studied at the English Language Education study program, they had different social, cultural, and economic backgrounds. The backgrounds that the students come from have an impact on the factor which causes them to learn or specialize in English and the type of motivation they have to do so.

Motivation plays a significant role in language learning (Gardner, 1995). The word motivation is derived from the word motive that means anything that encourages a person to act to do something. According to Elliot and Covington, (2001), motivation gives the reason for peoples' action, desire, and need. It was in line with Harmer's (2001) opinion that the success or failure of someone in learning English depends on his/her motivation to learn it. There are two types of motivation, those are instrumental motivation and integrative motivation (Gardner \& Lambert, 1959). Both motivations consist of several motives that affect the learner in achieving the goal in language learning. Integrative motivation is the individual effort of a person that wanted to learn the target language to facilitate communication with the target language community, which includes the attitude toward learning the target language factor, attitude toward the target language community factor, and the desire to learn the target language factor (Gardner, 1982). Meanwhile, instrumental motivation is the individual interest of the learner in learning the target language which is associated with the utilitarian benefits of language proficiency, which include economic factor social factor and academic factor (Donyei, 1990).

Since English language Education students come from different backgrounds, it might deliver an impact on the factor of students' motivation to learn English. It becomes an important question for why English language Education program always gets the most amount students rather than other program study. Therefore, the researcher is intended to analyze the factor of motivation and its dominant factors which affect students in learning English.

\section{METHOD}

\section{Design}

The study used mix-method approach with survey design. According to Cresswell (2014) survey is a research design that used to obtain or identify trend, opinions, behavior, or characteristic of certain subject. This research focused on analyzing motivation factors and the dominant factor of English Language

Education Students in acquiring their goal of English learning.

\section{Participants}

The study was conducted in Ganesha University of Education, specifically in English Language Education program, Bali, Indonesia. The subject was first semester students in English Language Education study program. The amount of the subject based on the data is 226 students. This subject is chosen because they are a fresh subject, which is not affected by other factors yet.

\section{Instruments}

The study used questionnaire and interview for collecting the data. The questionnaire was used to find out the integrative and instrumental factors which affect students in learning English. The questionnaire was mostly adapted on Attitude Motivation Test Battery (AMTB) which been used from several previous studies and had been reported to have good reliability and validity (Gardner, 1982; Gardner \& Smythe, 1981). The questionnaire consisted of 23 questions which are classified several factors such as: academic, social, economic, desire to learn the target language, attitude toward the target language and attitude toward the target language community. The questionnaire used Likert-scales from strongly agree to strongly disagree. Meanwhile, 
interview was employed as a supporting data. It used to give deeper understanding related to the research questions. The interview guide consisted of several questions related to how the major factor affect students in learning English.

\section{Data Analysis}

The data were analyzed through quantitative and qualitative method. The data from questionnaire was analyzed quantitatively aided with IBM SPSS Statistics 16.0. In addition, the interview data was qualitatively interpreted using Miles \& Huberman's, (1994) theory which involves data collection, data display, data reduction and conclusion/drawing verification.

\section{FINDINGS \& DISCUSSION}

Based on the analysis, there are 3 types of instrumental motivation factors that affect the students of ELE in learning English. Those factors were social, academic and economic factor. It can be seen in Table 1.

Table 1. The results of Instrumental Factor of Motivation

\begin{tabular}{ll}
\multicolumn{1}{c}{ Statement } & \multicolumn{1}{c}{$\begin{array}{c}\text { Factor of } \\
\text { Motivation }\end{array}$} \\
\hline $\begin{array}{l}\text { I choose English as a specialization because English is important } \\
\text { for me and it will make me as more knowledgeable person. }\end{array}$ & Academic \\
\hline $\begin{array}{l}\text { I choose English as a specialization because English offers a } \\
\text { better job opportunity. }\end{array}$ & Economic \\
\hline $\begin{array}{l}\text { Majoring in English may give me the chance to have better salary } \\
\text { later on. }\end{array}$ & Economic \\
\hline I choose English as a specialization in order to get a job aboard. & Economic \\
\hline Majoring English helps me to get a degree. & Academic \\
\hline $\begin{array}{l}\text { I choose English as a specialization in order to get an education } \\
\text { to serve my country. }\end{array}$ & Social \\
\hline My family inspired me to choose English as a specialization & Social \\
\hline I gain more respect in the society through majoring in English & Academic \\
\hline I prefer to read books and articles in English in order to get more \\
sources for my English assignment
\end{tabular}

Table 2. The results of Integrative Factor of Motivation 
The Art of Teaching English as a Foreign Language, Vol.1 No.2 2020

p-ISSN : 2656-8942, e-ISSN : 2684-8546

DOI: $10.36663 /$ tatefl.v1i2.83

I would like to know how to speak English more fluently.

Desire to Learn the Target

Language

I am interested in learning English language.

Attitude Toward Learning the Target Language

I learn English to know more about English literature.

Desire to Learn the Target

Language

Majoring in English can be important to me because it will help

Attitude Toward Learning

me to be able to participate more freely in the activity of English the Target Language

community.

English is desirable for having new experiences about the target language culture.

Desire to Learn the Target

Majoring English is important because it will enable me to get

involved in various cultures and people of the native speaker.

anguage

I would like to live in the countries where English is spoken.

Atude Toward Learning the Target Language

Desire to Learn the Target Language

I like to keep in touch with foreign friends and acquaintances.

I do like to make friends with English native speaker.

Attitude Toward Learning the Target Language

The more I learn about English, the more I like English. Attitude Toward Learning the Target Language

Attitude Toward Learning the Target Language

As indicated in Table 2, students were also affected by integrative motivation factors. The details of integrative motivation factor i.e. desire to learn the target language in the statements number $(14,16$ and 18$)$, attitude toward learning the target language in the statements number (15 and 23) and attitude toward the target language community in the statements number $(17,19,20,21$ and 22$)$. However, only two major motivation factors influence students to learn English. It can be seen in Figure 1 and 2.

Figure 1. Academic Motivation Factor

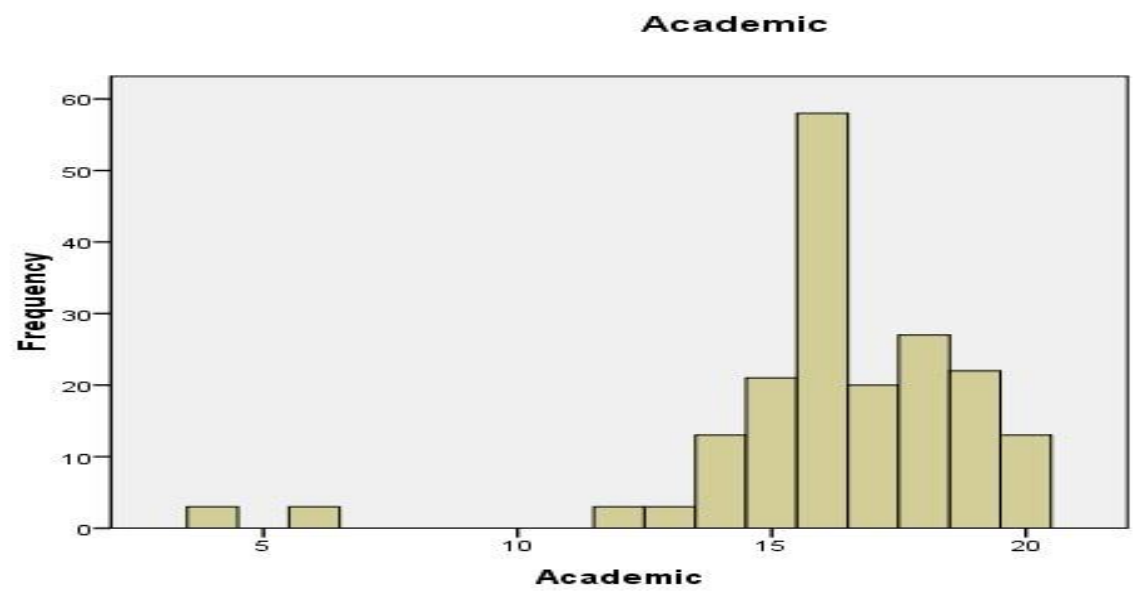

It clearly showed in Figure 1, the academic factor got 58 frequencies. Based on this finding, it can be concluded that in instrumental motivation, academic factor became the major factors among other factors. The academic factor influences English Language Education students in learning English by influencing their willingness in learning English to help them in achieving their objectives in learning English.

Figure 2. Attitude towards Learning the Target Language Factor 


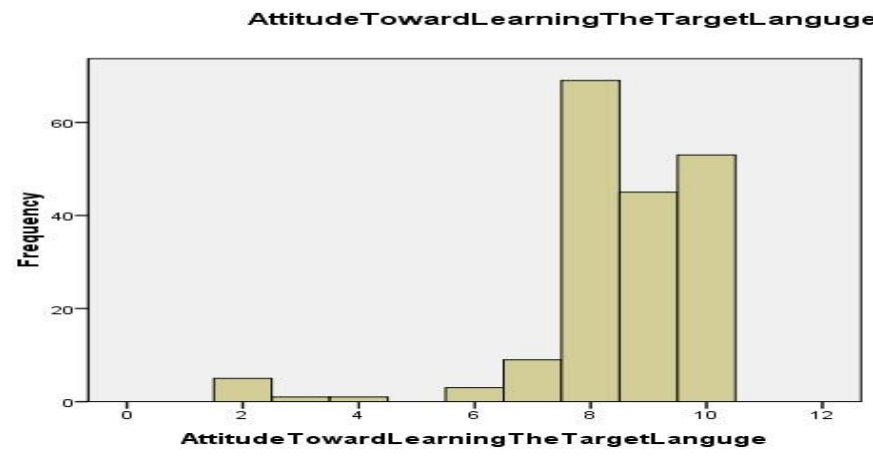

It clearly showed in Figure 1, the academic factor got 69 frequencies. Based on this finding, it can be concluded that attitude towards learning the target language was the major factor of integrative motivation. The attitude toward learning the target language affect students because it influences their attitude toward the learning English in order to get the full attention to learn English. As it stated previously, students' instrumental motivation factors were affected by three factors i.e., social factor, academic factor and economic factor. It was proven by questionnaire and interview with several students. This result finding was in line with a study by Hong and Ganapathy (2017), who found that the students of Chinese school in Penang were affected by three instrumental factors which were academic factor, social factors and economic factor. A study from Long, Ming and Chen (2013) shared a similar result which found that academic factor became the major factor in influencing students in learning English. The analysis showed that $66.7 \%$ students were affected by academic factor, $40 \%$ were affected by social factor, $36.7 \%$ affected by economic factor.

Furthermore, in integrative motivation, students were affected by three factors including desire to learn the target language, attitude toward learning the target language and attitude toward the target language community. This result was associated with Budiana and Djuwari's (2017) study who found that the students of STIE Perbanas were affected by the same 3 factors of integrative motivation. In addition, as the students of English Language Education, they were considered to have a willingness to enhance their knowledge about English. It might be attributed by instrumental and integrative motivation factors. The result was in line with Cook (2017) who studied about motivation in the learning second language. This study has revealed that there are two important types of motivation in learning a language as a second language, i.e., a learner might learn L2 well with an integrative motivation or instrumental motivation one, or indeed with both.

The major factors of motivation affected the students in learning English; they were affected by academic factor and attitude toward learning the target language. These two major factors affected students of ELE in learning English by encourage their willingness to learn English in order to achieved their goal in the future. It would enhance their knowledge or even getting master degree and scholarship to continue their education. Based on the finding and discussion, the study delivered some implications for lecturers. Since instrumental and integrative motivation factors provide a big influence towards students' motivation in learning English, lecturers should help students to keep their motivation in learning English.

\section{CONCLUSION}

Based on findings and discussion, there are 6 factors which affected English Language Education students' motivation in learning English, i.e. academic, social, economic, desire to learn the target language, attitude toward learning the target language 
and the attitude toward the target language community. Among these six factors, academic factor and the attitude toward learning the target language factor become the major factors of motivation which affected students to learn English. These two dominant factors influence them to achieve their future goal such as getting master degree and scholarship. It could be concluded that English Language Education Students were affected by six factors of motivation and two of them were chosen as the major factors to achieve their English learning's goal.

\section{REFERENCES}

Budiana, K.M., \& Djuwari. (2018). The non-native students' motivation in learning English at STIE Perbanas Surabaya. Language Circle: Journal of Language and Literature, 12(2), 195-202.

Cook, V. (2000). Second language learning and language teaching. Beijing: Foreign Language Teaching and Research Press.

Creswell, J. W. (2014). Research design, qualitative, quantitative, and mixed methods approach 4th edition. United State of America: Sage Publications

Crystal, D. (2003). English as a Global Language: 2nd ed. Cambridge: Cambridge University Press

Dornyei, Z. (1990). Teaching and researching motivation. Harlow, England: Longman.

Elliot, A. J., \& Covington, M. (2001). Approach and avoidance motivation.Educational Psychology Review. 13(2).

Fachraini, S. (2017). An analysis of students' motivation in studying english: (A Survey Study at UIN Ar-Raniry Banda Aceh).

Gardner, R., \& Lambert, W. (1959). Motivational variables in second language acquisition. Canadian Journal of Psychology.

Gardner, R.C. (1982). Social psychology and second language learning: The role of attitude and motivation. London: Edward Arnold.

Gardner, R. C., \& Smythe, P.C. (1981). On the development of the attitude/motivation test battery. Canadian Modern Language Review, 37, 510-525

Harmer, J. (2001). The practice of english language teaching: 3rd Ed. England: Longman.

Hong, Y. C., \& Ganapathy, M. (2017). To Investigate ESL Students' Instrumental and Integrative Motivation towards English Language Learning in a Chinese School in Penang: Case Study. English Language Teaching, 10(9), 17. https://doi.org/10.5539/elt.v10n9p17

Long, C., Ming, Z., \& Chen, L. (2013). The study of student motivation on English learning in Junior middle school -- A case study of No.5 middle school in Gejiu. English Language Teaching, 6(9), 136-145. https://doi.org/10.5539/elt.v6n9p136 